\title{
Comparison of costs for solar electric sources with diesel generators in remote locations
}

\author{
F. K. Manasse \\ Vice-President, AETA Corporation and Associate Director, Integrated Energy Systems Division,
} Center for Industrial and Institutional Development, University of New Hampshire, U.S.A.

(Reçu le 10 septembre 1979, accepté le 18 octobre 1979)

\begin{abstract}
This paper looks specifically at three alternative sources for generating power in remote regions of the world. These include diesel electric, photovoltaic and solar thermal electric devices. Fuel cost, and more specifically, transportation costs of that fuel, dramatically change which device will be most cost effective over a ten year period under specific conditions. In areas where fuel is readily available, diesel still appears to be the best alternative financially. Even today, however, solar thermal generators appear to make sense in a number of realistic scenarios, especially those involving LDCs. Photovoltaics do not yet seem to be competitive, but technical advances may in fact change this in the future. Cultural factors must also be taken into account when choosing a device. These comparisons are all represented graphically and numerically in the body of this paper.
\end{abstract}

1. Introduction. - The focus of this paper is to examine the relative merits of various devices capable of producing power in the 10 and $20 \mathrm{kWe}$ range for remote regions all over the world. Factors such as reliability, maintenance, and comparative costs are used to help determine precisely which devices would be of the most value under various conditions. These conditions would include availability and distances from supplies of conventional fuels, local technical expertise, climate, power needs, and alternatives available. All financial comparisons take into account the time value of money, a common business technique described briefly in this paper. This information is intended to clarify the market, specifically for small power stations in Lesser Developed Countries (LDCs) so that $\mathrm{R}$ and $\mathrm{D}$ organizations can better direct their efforts in these areas and private corporations can focus the marketing of their products more clearly. Cultural factors must also be taken into account when choosing a device for a given situation. These factors include such basic considerations as general acceptance by the people in question, and the availability of skilled technicians for maintenance requirements.

2. Background. - Saudi Arabia currently has a major program with the U.S. to assist them in solar energy development and deployment. Egypt, Kuwait, and other Arab countries as well as numerous African and Asian nations have major efforts currently devoted to small and large solar electric applications such as irrigation, desalination, and rural electrifi- cation. The major competing non-solar power sources for typical 200 family-sized villages which the sponsoring government plans to electrify in the next 5-10 years are gasoline or diesel generators [1]. This merely touches the surface of the worldwide interest in solar energy especially in third world countries. Traditionally, since the European countries once colonized these areas, they have retained considerable influence in selling to government, commercial, and private clients. Thus, to gain a market foothold in Africa and Asia, U.S. manufacturers must provide better, more reliable and cost effective solutions.

3. The rationale and methodology. - The previous discussion suggests that markets already exist for solar thermal electric products. However, such questions as to how large and how economically viable is the demand, where to place the emphasis on size and function of equipment, what timetable and approach to use for sales efforts, and others, must be answered before most U.S. manufacturers will proceed to invest their time, talent, and money to effect device development and production. A number of recent studies have focused on solar energy alternatives for this country but these merely hint at their relevance to foreign markets. While the U.S. potential for solar electric appears to be substantial only beyond the year 2000 , it is our contention that fossil fuel costs and lack of any other inexpensive energy alternative, in most LDCs, already make that substantial market attractive 
for solar powered sources, even within the next $10-20$ years. This is illustrated by figure 1 which is taken from a recent JPL study [2]. This figure showing equivalent bus bar electric costs vertically versus market size, illustrates the relative value of aiming for the LDC and non-U.S. island market in the near

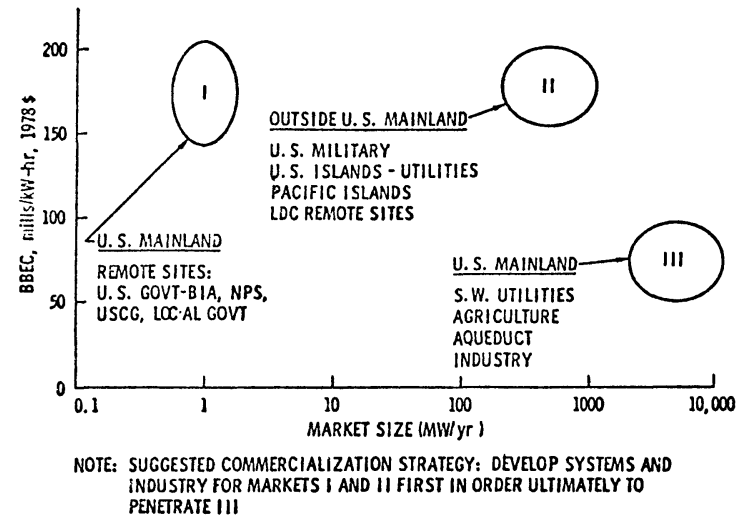

Fig. 1. - Potential market size and energy cost goals 1990-2000.

and mid-term. A second study, recently concluded by the author for JPL [3], attempts to identify targets of opportunities among the LDCs. For the 16 such typical countries selected, when cultural, social, economic and other factors are considered, the relative rankings are shown in chart I extracted from that report. These indicate that several countries such as Brazil, India and the West Indies are already better candidates than California in terms of similar indicators.

To evaluate this market accurately will require comparing all suitable solar related small electric power sources including wind, small-scale hydro and photovoltaic as well as thermal electric to the more conventional gasoline or diesel powered generators. We must do this on a common basis to assure meaningful results. Such considerations as capital costs, financing charges, maintenance fees, depreciation, life, inflation, fuel costs, special siting requirements, etc. must all be assessed fairly. For example, small-scale hydro requires extensive ponding and water containment structures to be built although annual generation and maintenance costs are quite low. On the other hand, diesel generators are inexpensive but annually consume substantial and costly fuel, require extensive and expensive maintenance, and produce pollutants.

4. Overall comparison of technologies selected. 4.1 Diesel. - 4.1.1 Positive. - Relatively inexpensive in areas where fuel is readily available.

- Sizing is easy.

- Portable.

Chart I. - Relative LDC rankings for solar thermal.

\begin{tabular}{|c|c|c|c|c|c|c|c|c|c|c|c|c|c|c|c|c|c|c|c|c|}
\hline \multirow[b]{2}{*}{ Characteristic } & \multirow[b]{2}{*}{$\stackrel{\tilde{N}}{\tilde{n}}$} & \multirow[b]{2}{*}{ 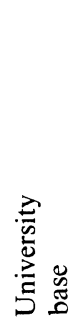 } & \multicolumn{4}{|c|}{$\begin{array}{l}\text { Government } \\
\text { agencies }\end{array}$} & \multirow[b]{2}{*}{ 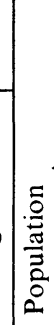 } & \multirow[b]{2}{*}{ 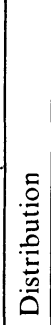 } & \multirow[b]{2}{*}{ 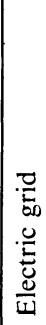 } & \multicolumn{5}{|c|}{ Economy } & \multirow[b]{2}{*}{$\frac{0}{3}$} & \multirow[b]{2}{*}{ 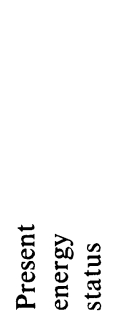 } & \multirow[b]{2}{*}{ 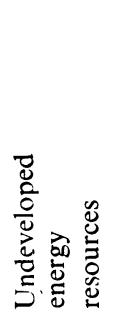 } & \multirow[b]{2}{*}{ 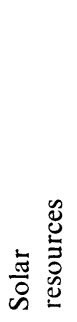 } & \multirow[b]{2}{*}{ 焉泀 } & \multirow[b]{2}{*}{ 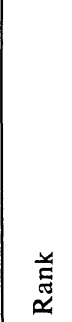 } \\
\hline & & & 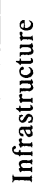 & 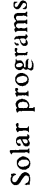 & 占 & 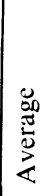 & & & & Z & $\frac{0}{\frac{0}{3}}$ & 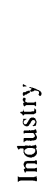 & 吾 & 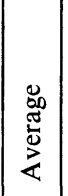 & & & & & & \\
\hline $\begin{array}{c}\text { Weight } \\
\text { (multiplier) }\end{array}$ & 1 & 1 & & & & 2 & 1 & 1 & 2 & & & & & & 2 & 3 & 3 & 3 & & \\
\hline Brazil & 5 & 5 & 5 & 5 & 4 & 4.5 & 4 & 4 & 4 & 5 & 5 & 5 & 5 & 5 & 5 & 4 & 3 & 3 & 85.4 & 1 \\
\hline Colombia & 3 & 3 & 3 & 4 & 3 & 3.3 & 3 & 3 & 3 & 2 & 2 & 2 & 3 & 2.25 & 3 & 2 & 2 & 2 & 47.1 & 16 \\
\hline Costa Rica & 1 & 1 & 4 & 4 & 4 & 4 & 1 & 2 & 4 & 1 & 1 & 1 & 1 & 1 & 3 & 5 & 1 & 3 & 56 & 15 \\
\hline Greece & 2 & 2 & 4 & 5 & 4 & 4.3 & 2 & 2 & 1 & 2 & 1 & 2 & 2 & 1.75 & 4 & 3 & 2 & 5 & 60.1 & 12 \\
\hline India & 4 & 5 & 3 & 5 & 5 & 4.3 & 5 & 5 & 3 & 5 & 5 & 3 & 5 & 4.5 & 3 & 4 & 3 & 5 & 81.6 & 2 \\
\hline Jamaica & 1 & 2 & 2 & 2 & 1 & 1.7 & 1 & 1 & 4 & 1 & 1 & 1 & 1 & 1 & 4 & 5 & 4 & 4 & 65.4 & 6 \\
\hline Malawi & 1 & 1 & 2 & 2 & 1 & 1.7 & 2 & 3 & 3 & 1 & 2 & 1 & 1 & 1.25 & 2 & 5 & 4 & 4 & 61.9 & 11 \\
\hline Nigeria & 3 & 3 & 4 & 3 & 2 & 3 & 4 & 5 & 4 & 3 & 2 & 2 & 3 & 2.5 & 4 & 1 & 1 & 4 & 60 & 13 \\
\hline Pakistan & 3 & 3 & 4 & 4 & 3 & 3.7 & 3 & 4 & 4 & 2 & 3 & 1 & 2 & 2 & 4 & 3 & 2 & 3 & 64.4 & 7 \\
\hline Papua New Guinea & 3 & 2 & 1 & 2 & 1 & 1.3 & 1 & 2 & 5 & 1 & 2 & 1 & 1 & 1.25 & 1 & 3 & 3 & 3 & 56.1 & 14 \\
\hline Senegal & 2 & 2 & 2 & 1 & 1 & 1.3 & 2 & 2 & 5 & 1 & 2 & 1 & 1 & 1.25 & 2 & 5 & 4 & 4 & 66.1 & 5 \\
\hline Sri Lanka & 1 & 1 & 1 & 2 & 1 & 1.3 & 2 & 3 & 5 & 1 & 3 & 1 & 1 & 1.5 & 2 & 5 & 3 & 4 & 62.6 & 10 \\
\hline Tanzania & 3 & 1 & 4 & 2 & 2 & 2.7 & 2 & 4 & 3 & 1 & 3 & 1 & 1 & 1.5 & 4 & 3 & 3 & 4 & 62.7 & 4 \\
\hline Thailand & 3 & 3 & 4 & 4 & 4 & 4 & 3 & 4 & 4 & 2 & 2 & 3 & 3 & 2.5 & 3 & 4 & 3 & 3 & 70 & 3 \\
\hline Turkey & 3 & 4 & 3 & 3 & 2 & 2.7 & 3 & 3 & 3 & 3 & 3 & 3 & 3 & 3 & 3 & 3 & 3 & 3 & 63.4 & 8 \\
\hline West Indies & 3 & 2 & 2 & 2 & 2 & 2 & 1 & 3 & 5 & 2 & 3 & 1 & 2 & 2 & 3 & 4 & 4 & 4 & 69 & 4 \\
\hline New England & 2 & 5 & 3 & 3 & 2 & 2.7 & 2 & 2 & 1 & 3 & 2 & 3 & 2 & 2.5 & 5 & 4 & 3 & 3 & 63.4 & $8(*)$ \\
\hline California & 3 & 5 & 5 & 5 & 5 & 5 & 2 & 4 & 2 & 4 & 4 & 4 & 5 & 4.25 & 5 & 3 & 3 & 4 & 76.5 & $3(*)$ \\
\hline
\end{tabular}

(*) Equivalent rank. 
- Time proven and tested.

- Many manufacturers.

- Maintenance uses standard tools and techniques.

4.1.2 Negative. - Frequent and costly maintenance of diesel generating systems by skilled mechanics.

- Diesel engine replacement every five to seven years.

- Non-availability of skilled diesel generator mechanics in developing countries.

- The need for automatic transfer switches and starting equipment, adding significantly to the cost.

4.2 Thermal electric. - 4.2.1 Positive. - Large sizes possible.

- Collectors are durable.

- Mechanical portions are standard.

- Shaft Horse Power available.

- Steam or air as working fluids.

- Energy storage means are simpler.

- Reasonably transportable.

4.2.2 Negative. - Small sizes are uneconomical $(<10 \mathrm{~kW})$.

- Expensive.

- Maintenance on mechanical and optical parts necessary.

- Technology unproven in commercial sense.

- Potential hazard to humans.

4.3 Pнotovoltaic. - 4.3.1 Positive. - Low maintenance.

- Small yearly operational cost.

- No fuel transportation necessary.

- Power requirements may be exactly adjusted.

- Long life.

- Quiet.

- Environmentally adaptable.

4.3.2 Negative. - Very large initial expense.

- Solar array must be oversized due to reduced effectiveness caused by wind, dust, or yearly climatic variations.

- Harsh environmental conditions may cause cells to delaminate.

- Very large battery arrays are necessary for storage during periods of unfavorable weather, greatly increasing the cost of this form of energy.

The method we have chosen is often used by business managers in large industrial companies who must generally compare alternative technologies and products for a given application. The method is known as Net Present Value (NPV) Analysis and is briefly described in the following section. Through its use we will be able to compare all costs on an equivalent basis and thereby formulate some general conclusions that could be used for market analysis by any manufacturer. Using this NPV methodology, we will specifically compare three equivalent sources from the energy viewpoint at
2 power levels : (1) two small solar thermal electric generators, one Steam/Rankine (a) $10 \mathrm{kWe}$, the other, a more advanced Air/Brayton (a) $20 \mathrm{kWe}$; (2) Photovoltaic Generators (P/V) @ 12 and $24 \mathrm{kWe}$; (3) Diesel Generators (a) 10 and $20 \mathrm{kWe}$. All sources are sized to provide essentially the same number of kilowatt hours/years namely :

$$
\begin{aligned}
& « 10 \mathrm{~kW} » \leftrightarrow 22000 \mathrm{kWh} / \text { year } \\
& « 20 \mathrm{~kW} » \leftrightarrow 44000 \mathrm{kWh} / \text { year }
\end{aligned}
$$

The systems being compared all provide energy in electrical forms. However, diesel and thermal engines can also provide shaft horsepower. The thermal generator can also provide useful heat in the form of waste air or steam. Thus, any strict economic comparison should also be assessed with these added benefits for any given LDC application.

5. Assumptions. - Although the specific assumptions made are stated on the attached charts, cost of money and inflation rates of $10 \%$ are generally considered. The fuel transportation charges shown in table I were obtained from several sources including the Commerce Department, Postal Service, and commercial shipping and trucking firms. A 10 years assessment period was chosen for all systems as being typical, minimal value for life expectancy of solar technologies.

\begin{tabular}{|c|c|c|}
\hline Mode & Cost range & in analys \\
\hline - & - & - \\
\hline Air & $\$ 0.18-1.00 / 1 \mathrm{~b}-1000 \mathrm{mi}$ & $\$ 0.40$ \\
\hline Land & $\$ 0.10-0.25 / 1 \mathrm{~b}-1000 \mathrm{mi}$ & 0.15 \\
\hline Sea & $2-6 \$ / 1 b-1000 \mathrm{mi}$ & 0.05 \\
\hline Helicopter & $\$ 1.00 / \mathrm{lb}-100 \mathrm{mi}$ & 1.00 \\
\hline
\end{tabular}

Table I. - Fuel transportation costs.

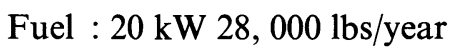

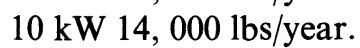

6. Net present value analysis. - An investor prefers to have a dollar today as opposed to a dollar a year from now. If he receives the dollar today, he can invest the dollar and have more than a dollar returned at the end of the year. If he foregoes the dollar today, an opportunity cost is involved - the opportunity represented by the earnings he could have received on his dollar. This opportunity cost leads to the time value of money; that is, the real value of a cash flow is determined not only by the amount of the cash, but also by the time at which it is received. Conversely, the real cost of money spent is also determined by the time at which this 
expenditure occurs. Money spent earlier during a period of cash outflows will thus have a greater opportunity cost at the end of a given period of time than will money spent later. Opportunity costs are very real expenses in doing business, and any analysis that does not take this factor into account in examining cash flows is simply not correct. Table II shows this more clearly.

Table II.

\begin{tabular}{|c|c|c|c|}
\hline Year & $\begin{array}{c}\text { Accumulated } \\
\text { value of } \$ 1 @ 10 \%\end{array}$ & Year & $\begin{array}{c}\text { Accumulated } \\
\text { value of } \$ 1 @ 10 \%\end{array}$ \\
\hline- & - & - & - \\
\hline 1 & $\$ 1.00$ & 6 & $\$ 1.61$ \\
\hline 2 & 1.10 & 7 & 1.77 \\
\hline 3 & 1.21 & 8 & 1.95 \\
\hline 4 & 1.33 & 9 & 2.14 \\
\hline 5 & 1.46 & 10 & 2.36 \\
\hline
\end{tabular}

As an example then, $\$ 9000$ received in year one would be worth $\$ 21222(\$ 9000 \times 2358)$ in year ten. Conversely, receiving $\$ 21222$ in ten years is totally equivalent to receiving $\$ 9000$ today if a $10 \%$ opportunity cost is assumed [4].

This methodology is consequently used in this report to compare remote power sources which have drastically different cash outflow patterns over the life of the device's operation. Accumulated Value and Net Present Value accomplish almost exactly the same task when comparing a stream of cash flows. Accumulated Value simply looks at the total value of the cash flows at the end of the period in question, whereas Net Present Value discounts the stream of cash flows back into today's dollars. We have chosen to look at the Accumulated Value of all cash flows after 10 years.

7. Parametric analysis of alternatives. - Calculations for the thermal electric and photovoltaic devices were fairly simple. Initial capital expenditures and maintenance costs were determined from manufacturer's estimates; the Accumulated Value of these cash flows were then determined directly. The following formulas show how this may be done :

In general :

$$
A V=P\left[\frac{(1+i)^{N}-1}{i}\right]
$$

Where :

$A V=$ accumulated value,

$P \quad=$ annual payment or expenditure,

$i=$ interest rate,

$N=$ number of years.

In this case :

$$
P=\left(F X_{1}+G X_{2}\right) \quad(365 \text { days } / \text { year })
$$

where :

$F=$ pounds of fuel consumed per day,

$X_{1}=$ cost of transport $\left({ }^{1}\right)$,

$G=$ gallons of fuel consumed per day,

$X_{2}=$ cost of fuel $\left({ }^{1}\right)$.

Also for this case, using $10 \%$ interest for 10 years ;

$\left[\frac{(1+i)^{N}-1}{i}\right] \rightarrow$ reduces to $(1.594) \quad(10$ years $)$

so the final equation becomes :

$$
A V=\left(F X_{1}+G X_{2}\right)(365)(1.594)(10) \text {. }
$$

In the case of diesel electric devices, many more variables had to be calculated. These included fuel consumption for given levels of power output, fuel cost and inflation rates, and transportation costs by air, land and sea. The following formulas and information should help document these calculations, all of which were then of course discounted to determine the Accumulated Value in Year 10.

Diesel facts and formulas. - $\mathrm{kVA}=\mathrm{kilovolt}$ amperes,

$$
\begin{aligned}
& \mathrm{kW}=\text { kilowatts } \\
& \mathrm{HP}=\text { horsepower }
\end{aligned}
$$

$$
\begin{aligned}
12.5 \mathrm{kVA} & \cong 10 \mathrm{~kW} \\
1.5 \mathrm{~kW} & \cong 1 \mathrm{HP}
\end{aligned}
$$

gallons/hour $=$

$$
=\frac{\mathrm{HP} \times 0.42 \text { (fuel consumption } \mathrm{lbs} / \text { brake HP hour) }}{7.2 \text { pounds/gallon }} .
$$

Thus, a $10 \mathrm{~kW}$ plant would use :

$$
\frac{(10 \mathrm{~kW}) 1.5 \times 0.42 \mathrm{lbs} / \mathrm{HP}}{7.2 \mathrm{lbs} / \text { gallon }}=0.9 \text { gallons } / \text { hour }
$$

or about 6.5 pounds/hour.

The following charts give a numerical analysis of the costs associated with the various alternatives for power generation in remote areas. Chart II is a detailed analysis of NPV totals for a $20 \mathrm{~kW}$ diesel system with 1000 miles of transportation for fuel necessary. This chart can be summarized and the totals used to obtain additional numerical summary charts of incremental costs for different distances and types of transport as illustrated in chart III. A similar analysis can be made for $10 \mathrm{~kW}$ systems. These and other more detailed assessments can be found in reference [3]. One such comparison provides a useful example and is given for a specific scenario

( $\left.{ }^{1}\right)$ For a constant inflation rate $R$ over 10 years in either transport cost or fuel the following calculation can be made and was in fact used in this report :

$$
\bar{X}_{A V}=X\left[\frac{(1+R)^{N}-1}{R N}\right] .
$$


of a Sahara desert location and is illustrated in table III. This clearly demonstrates the importance of fuel and its transportation costs as time advances on

Table III. - Typical scenario : Sahara desert. 1000 miles. Air plus 500 miles. Land.

Accumulated cost

$\begin{array}{rr}\text { Year } & 10 \mathrm{~kW} \\ - & - \\ 1 & 19 \\ 2 & 33 \\ 3 & 50 \\ 4 & 67 \\ 5 & 88 \\ 6 & 121 \\ 7 & 149 \\ 8 & 184 \\ 9 & 221 \\ 10 & 264\end{array}$

$20 \mathrm{~kW}$

32

56

88

120

159

216

268

332

402

484 opportunity capital demands. Figures 2 and 3 show this also.

To use this type of information for comparison then, we will use a standard 1000 mile distance in

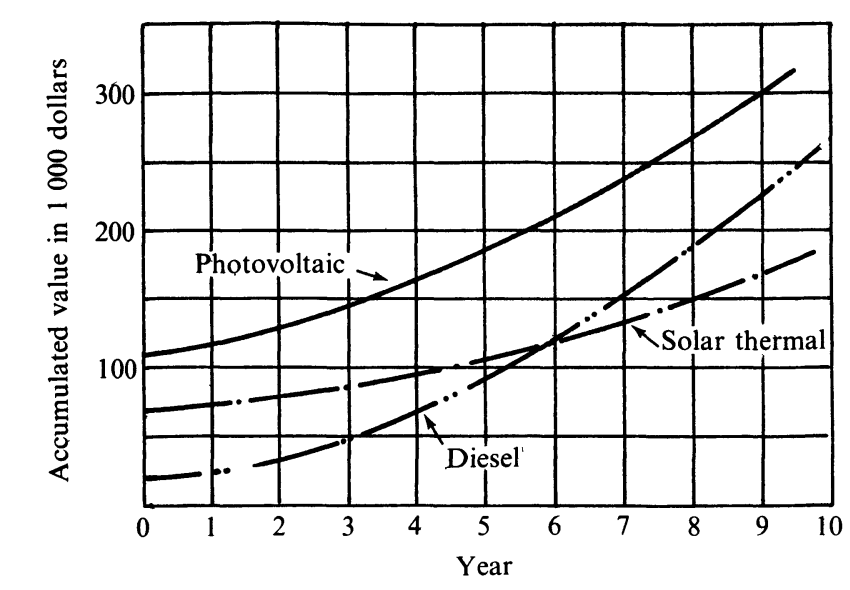

Fig. 2. - Sahara desert scenario, $10 \mathrm{~kW}$.

Chart II. - $20 \mathrm{~kW}$ diesel.

Year
1
2
3
4
5
6
7
8
9
10
expenditur
/V in year $10\left(^{1}\right)$

in thousands.)
inflation.
inflation, 1000 miles average transport.

\begin{tabular}{ccrrr} 
Maintenance & Fuel $\left({ }^{2}\right)$ & \multicolumn{3}{c}{ Transportation $\left({ }^{3}\right)$} \\
cost & cost & Air & Land & Sea \\
- & - & - & - & - \\
$\$ 2$ & $\$ 2.4$ & $\$ 11.2$ & $\$ 4.2$ & $\$ 1.4$ \\
2 & 2.6 & 12.3 & 4.6 & 1.5 \\
7 & 2.9 & 13.6 & 5.1 & 1.7 \\
3 & 3.2 & 14.9 & 5.6 & 1.9 \\
4 & 3.5 & 16.4 & 6.1 & 2.1 \\
2 & 3.9 & 18.0 & 6.8 & 2.3 \\
2 & 4.3 & 19.8 & 7.4 & 2.5 \\
7 & 4.7 & 21.8 & 8.2 & 2.7 \\
3 & 5.2 & 24.0 & 9.0 & 3.0 \\
4 & 5.7 & 26.4 & 9.9 & 3.3 \\
$\$ 56$ & $\$ 57$ & $\$ 264$ & $\$ 99$ & $\$ 33$
\end{tabular}

(All figures in thousands.)

( $\left.{ }^{1}\right)$ See accompanying explanation

(2) $10 \%$ inflation

( $\left.{ }^{3}\right) 10 \%$ inflation, 1000 miles average transport.

Chart III. - Incremental costs.

$20 \mathrm{~kW}$

\begin{tabular}{crcc}
$\begin{array}{c}\text { No trans. } \\
\text { capital costs } \\
\text { plus fuel }\end{array}$ & \multicolumn{3}{c}{500 miles } \\
- & Air & Land & Sea \\
19 & - & - & - \\
26 & 6 & 2 & 1 \\
39 & 13 & 5 & 2 \\
49 & 21 & 8 & 3 \\
61 & 30 & 11 & 4 \\
87 & 41 & 16 & 5 \\
103 & 54 & 21 & 7 \\
124 & 70 & 26 & 9 \\
145 & 88 & 33 & 11 \\
170 & 108 & 41 & 14 \\
& 132 & 50 & 17
\end{tabular}

Transportation costs

\begin{tabular}{|c|c|c|c|c|c|c|c|}
\hline \multicolumn{2}{|c|}{1000 miles } & \multicolumn{3}{|c|}{1500 miles } & \multicolumn{3}{|c|}{2000 miles } \\
\hline Land & Sea & Air & Land & Sea & Air & Land & Sea \\
\hline- & - & - & - & - & - & - & - \\
\hline 4 & 1 & 17 & 6 & 2 & 22 & 8 & 2 \\
\hline 9 & 3 & 38 & 14 & 5 & 50 & 18 & 6 \\
\hline 15 & 5 & 62 & 23 & 8 & 82 & 30 & 10 \\
\hline 22 & 7 & 90 & 33 & 11 & 120 & 44 & 14 \\
\hline 31 & 10 & 123 & 47 & 15 & 164 & 62 & 20 \\
\hline 41 & 14 & 162 & 63 & 21 & 216 & 82 & 28 \\
\hline 52 & 17 & 209 & 78 & 26 & 278 & 104 & 34 \\
\hline 65 & 22 & 263 & 98 & 33 & 350 & 130 & 44 \\
\hline 81 & 27 & 324 & 122 & 41 & 432 & 162 & 54 \\
\hline 99 & 33 & 396 & 149 & 50 & 528 & 198 & 66 \\
\hline
\end{tabular}




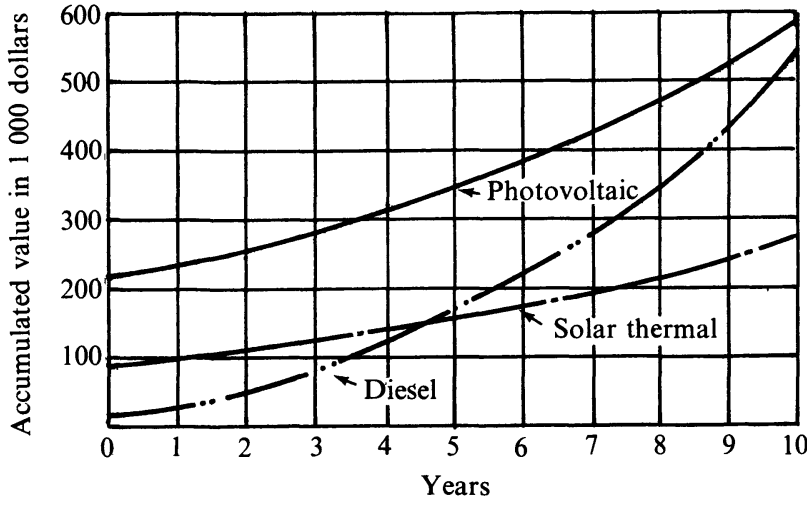

Fig. 3. - Sahara desert scenario, $20 \mathrm{~kW}$.

the analysis that follows. Chart IV summarizes the 10 and $20 \mathrm{~kW}$ diesel findings. This is followed by summary charts for each of the other systems taking into account such factors as initial cost, maintenance requirements, inflation and the timing of each cash expenditure. Calculations for the thermal electric and photovoltaic devices were fairly simple. Initial capital expenditures and maintenance costs were determined from manufacturer's estimates; the Accumulated Value of these cash flows was then determined directly. These results are then shown

\section{Chart IV.}

\section{A. $20 \mathrm{~kW}$ diesel summary}

\begin{tabular}{lrrr} 
& \multicolumn{1}{c}{ Air } & \multicolumn{1}{c}{ Land } & \multicolumn{1}{c}{ Sea } \\
Capital expenditures & $\$ 57\left(^{*}\right)$ & $\overline{-}$ & - \\
Maintenance & 56 & 56 & $\$ 57$ \\
Fuel & 57 & 57 & 56 \\
Transportation & 264 & 99 & 57 \\
Total A/V & $\$ 434$ & $\$ 269$ & $\$ 203$
\end{tabular}

B. $10 \mathrm{~kW}$ diesel summary

Capital expenditure

Air
$\$ 34$
44
29
132
$\$ 239$

Maintenance

Fuel

Transportation

Total A/V

$\$ 239$

$\left(^{*}\right)$ All figures equal $\mathrm{K} \$$.
Chart V. - Solar thermal electric summary.

Capital expenditure $10 \mathrm{~kW}$ $20 \mathrm{~kW}$

Maintenance

$\$ 163$

$\$ 16$

$\$ 179$

$\$ 236$

$\$ 16$

$\$ 252$

(All figures in $\mathrm{K} \$$ ).

in charts $\mathrm{V}$ and VI. Using all these summaries, we obtain a comparison chart for $A V$ and equivalent cost $/ \mathrm{kWh}$ of all options considered shown as chart VII [5]. From this chart it is evident that costs $/ \mathrm{kWh}$ can vary substantially but that solar thermal electric devices are already quite competitive even at 1000 mile distances.

To give a more easily absorbed visual comparison we compare the costs of the various systems under discussion graphically. Figures on the vertical axis represent the Accumulated Value of cash flows for each system after ten years. The horizontal axis describes the number of miles that fuel must be transported. Systems that have no fuel to transport will obviously show a line parallel to the horizontal axis. Points of intersection represent systems of equal cost under the conditions represented by that point on the graph. Figure 4 gives a $10 \mathrm{~kW}$ comparison which indicates that the solar thermal electric scheme is more cost effective only if air transport greater

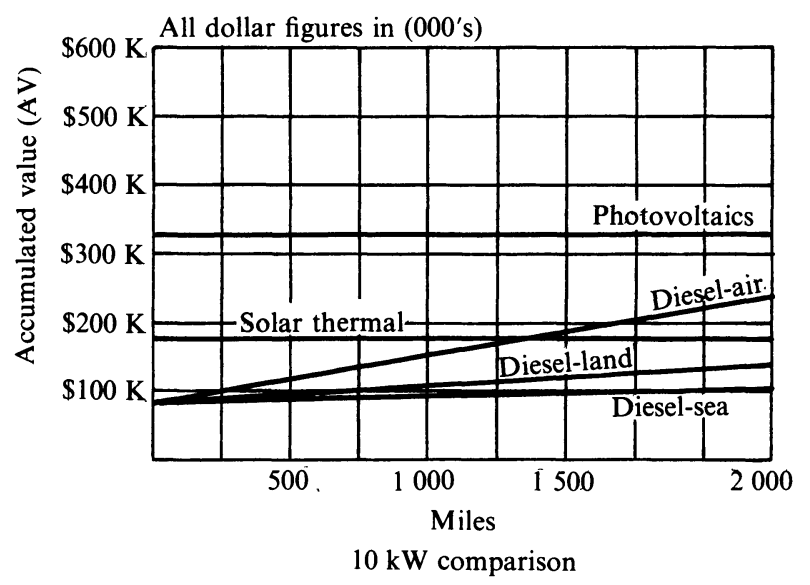

Fig. 4.

Chart VI.

Photovoltaic summary $\left({ }^{1}\right)$

$\begin{array}{lrr} & 12 \mathrm{kWp} & 24 \mathrm{kWp}\left(^{2}\right) \\ \text { Capital expenditure } & - & - \\ \text { Maintenance } & \$ 283 & \$ 566 \\ \text { Battery } & 16 & 32 \\ \text { Total A/V } & 23 & 46 \\ & \$ 322 & \$ 644\end{array}$

Photovoltaic cost vs. cost $/ \mathrm{Wp}\left[{ }^{3}\right]$

$$
\text { Cost/peak watt }
$$

\begin{tabular}{cccccc} 
Array size & \multicolumn{1}{c}{20} & 10 & 5 & 2 & 1 \\
- & - & - & - & - & - \\
$12 \mathrm{kWp}$ & $600 \mathrm{~K} \$$ & 320 & 180 & 100 & 70 \\
$24 \mathrm{kWp}$ & $1200 \mathrm{~K} \$$ & 640 & 360 & 190 & 130
\end{tabular}

( ${ }^{1}$ Assumes $\$ 10 / \mathrm{Wp}$ and $60 \mathrm{kWh} /$ day.

(2) All figures for $24 \mathrm{kWp}=2(12 \mathrm{kWp})$, assumes $120 \mathrm{kWh} /$ day.

$\left({ }^{3}\right)$ Compares total accumulated value of cash flows over 10 years. 
Chart VII. - Comparison of alternatives.

$\begin{array}{ccccc}\text { Device } & \text { No transp. } & \text { Air } & \text { Land } & \text { Sea } \\ - & - & - & - & - \\ \text { Diesel } & & & & \\ & & & & \\ 20 \mathrm{~kW} & 170\left(^{*}\right) & 434 & 269 & 203 \\ & (0.39)\left(^{+}\right) & (0.93) & (0.62) & (0.46) \\ 10 \mathrm{~kW} & 107 & 239 & 157 & 124 \\ & (0.49) & (1.10) & (0.70) & (0.57)\end{array}$

$\left.{ }^{*}\right)$ Indicates $\mathrm{AV}$ over 10 years.

$(+)$ Indicates cost $/ \mathrm{kWh}$ over 10 years.

Assumes $22000 \mathrm{kWh} / \mathrm{yr}$ for $10 \mathrm{~kW}$ systems.

Assumes $44000 \mathrm{kWh} / \mathrm{yr}$ for $20 \mathrm{~kW}$ systems.

Device

than 1300 miles is required. Similarly figure 5 indicates that even at distances as short as 500 miles solar thermal electric is best.

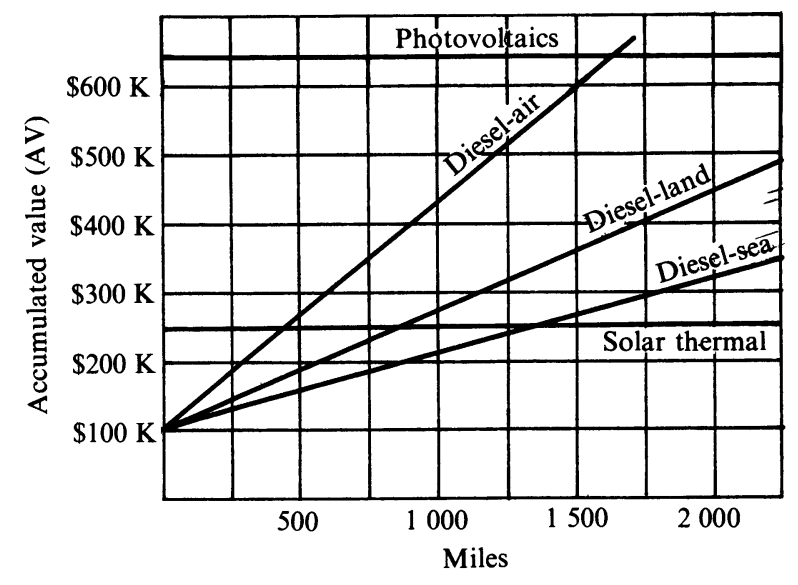

$20 \mathrm{~kW}$ comparison

Fig. 5.

Various scenarios involving fuel transport were also considered simply as working examples. More work needs to be done to determine real situations more precisely, but the following order of preference is obtained from the analysis above for typical possibilities (Table IV).

Table IV. - Scenarios and optimal choices.

\begin{tabular}{|c|c|c|}
\hline \multicolumn{3}{|c|}{$10 \mathrm{~kW}$} \\
\hline 500 mi. by sea & 1000 mi. by land & $2000 \mathrm{mi}$. by air \\
\hline 1. Diesel & 1. Diesel & 1. Solar thermal \\
\hline 2. Solar thermal & 2. Solar thermal & 2. Diesel \\
\hline 3. Photovoltaic & 3. Photovoltaic & 3. Photovoltaic \\
\hline \multicolumn{3}{|c|}{$20 \mathrm{~kW}$} \\
\hline $500 \mathrm{mi}$. by sea & $1000 \mathrm{mi}$. by land & 2000 mi. by air \\
\hline 1. Diesel & 1. Solar thermal & 1. Solar thermal \\
\hline 2. Solar thermal & 2. Diesel & 2. Photovoltaic \\
\hline 3. Photovoltaic & 3. Photovoltaic & 3. Diesel \\
\hline
\end{tabular}

A further graphical comparison can be made which it appears [6] can provide some interesting future

marketing strategies for the industry. Here we have plotted the Net Present Values directly rather than the Accumulated NPV after 10 years. These curves demonstrates that for a given distance and type of fuel delivery the cost equivalency for using non diesel or solar electric sources already occurs at a reasonable payback period which is considerably less than the 10 years system life anticipated. Considerably more such analysis and scenario development with more up to date discount rates, fuel, equipment and labor costs should be performed to solidify the findings (Figs. 6-8).

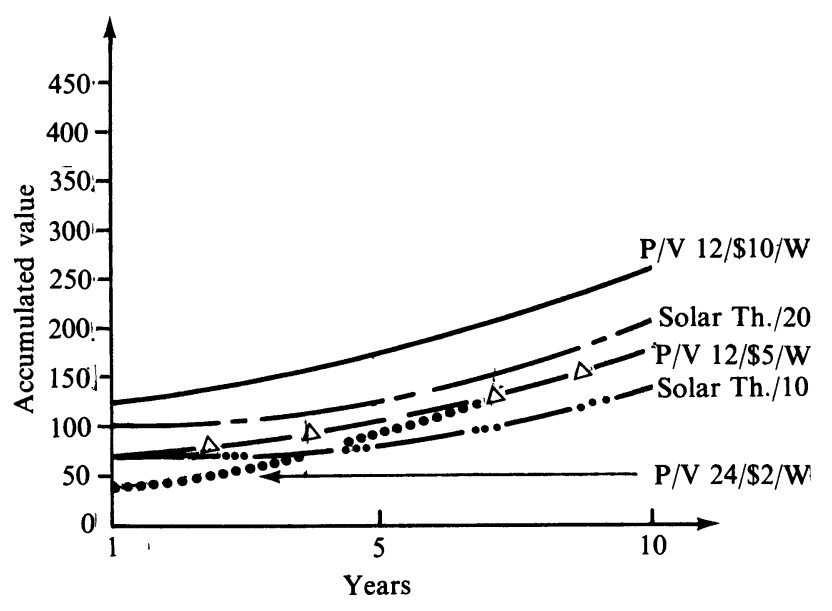

Fig. 6 .

Accumulated value comparison

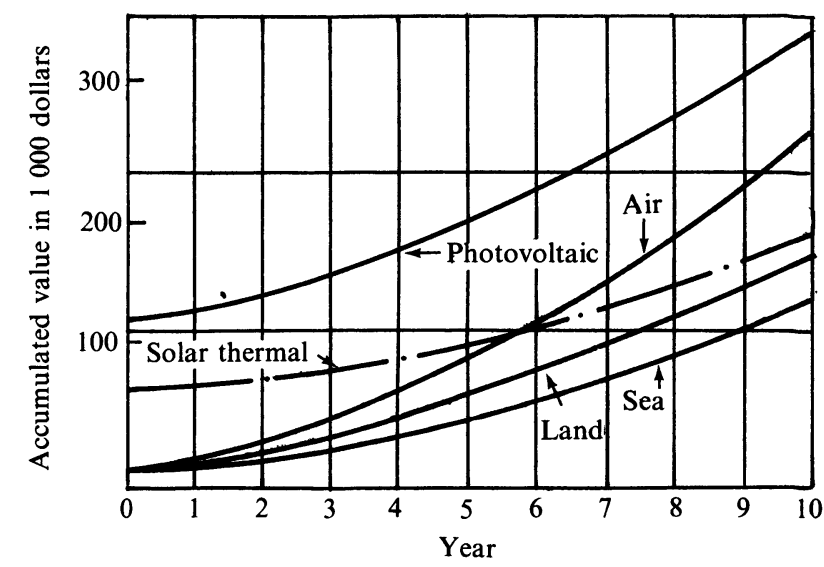

Fig. 7. $-10 \mathrm{~kW}$ diesel transport comparison, 1000 miles. 


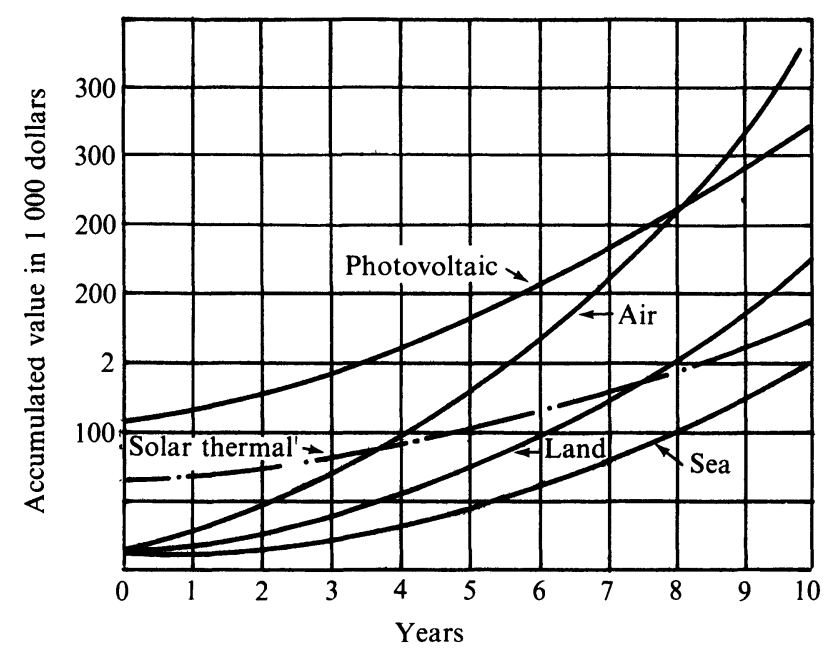

Fig. 8. $-10 \mathrm{~kW}$ diesel transport comparison, 2000 miles.
8. Summary. - The above analysis is merely a first attempt to develop comprehensive comparisons of differing technologies to produce electric power at small remote sites. However, as the charts and figures show, especially the Sahara Desert scenario figures 2 and 3, it would already appear that in many LDC's there exist applications where solar thermal power systems make economic sense. This is easy to see from the graphs shown, especially figures 6 and 7.

The overall comparison demonstrates the primary thesis - solar thermal systems of small size can compete - when proper cost assessments are made. The study should be expanded to cover other renewable resource technologies as well as larger size systems.

\section{References}

[1] Manasse, F. K. and Borofsky, R. L., Market Comparisons of Small Remote Solar Thermal Electric Technologies and Diesel Generators, AETA Report to DOE Solar Thermal Program, Sept. 1978.

[2] Bluhm, S. A., Economic Values of Small Solar Thermal Electric Power Systems, JPL Presentation (a) Solar Thermal Power Semi-Annual Mtg. (a) SERI, Denver, CO., April 1979.

[3] Borofsky, R. L. and Manasse, F. K., Less Developed Country Market Overview for Small Power System Applications Project, AETA Reports to JPL, April and June 1979.

[4] Time Value of Money, Harvard Business School \# 4-172-060.
[5] Manasse, F. K. and Borofsky, R. L., Comparison of Costs for Solar Derived Electrical Sources with Diesel Generators in Remote Locations, Presentation at ISES Silver Jubilee, June 1, 1979, Atlanta, GA. To be included in proceedings, Winter 1979.

[6] Borofsky, R. L. and Manasse, F. K., Evaluation of Potential Markets for Small Solar Thermal Generators in LDC's, AETA Corporation Report to Sanders Associates, Jan. 1979.

[7] Presented at SEIA Solar Power Meeting in San Jose CA. August 9, 1979. 